\title{
Adsorption, viscosity and thermal behaviour of nanosized proteins with different internal stability immobilised on the surface of mesoporous activated biocarbon obtained from the horsetail herb precursor
}

\author{
Małgorzata Wiśniewska ${ }^{1}$ (1) - Dariusz Sternik ${ }^{2}$ - Piotr Nowicki ${ }^{3}$ - Stanisław Chibowski ${ }^{1}$ Magdalena Medykowska ${ }^{1}$. \\ Marlena Gęca ${ }^{1} \cdot$ Katarzyna Szewczuk-Karpisz ${ }^{4}$
}

Received: 21 January 2021 / Accepted: 17 February 2021 / Published online: 6 March 2021

(c) The Author(s) 2021

\begin{abstract}
The thermal analysis methods were used for the description of the adsorption behaviour of selected proteins differing in internal stability (ovalbumin (OVA) and lysozyme (LSZ)). These proteins were immobilised on the surface of activated biocarbon obtained from the horsetail herb precursor. The values of the hydrodynamic radius of both biopolymer macromolecules in the solution were determined by the use of the viscosimetry method. This parameter is important for the specification of the possibility of proteins nano-molecules to penetrate the nano-pores of the adsorbent which leads to the increase of biopolymers adsorption. Such behaviour is observed at the $\mathrm{pH}$ value which is very close to the $\mathrm{pI}$ value of specific biopolymer (the greatest adsorption of proteins on the activated carbon surface occurs- at $\mathrm{pH} 5$ for OVA being $323 \mathrm{mg} / \mathrm{g}$, as well as at pH 11 for LSZ which is $464 \mathrm{mg} / \mathrm{g}$ ). Under such conditions, the proteins macromolecules assume conformations characterized by the lowest values of hydrodynamic radius, i.e. $2.76 \mathrm{~nm}$ for OVA and $1.07 \mathrm{~nm}$ for LSZ. The data obtained from the analysis of gaseous products of thermal decomposition of the samples indicated the types of biocarbon surface groups as well as the enabled specification of the protein macromolecules adsorption mechanism.
\end{abstract}

Keywords Nanosized proteins · Thermal analysis · Adsorption mechanism · Activated carbon decomposition · Hydrodynamic radius of macromolecules $\cdot$ Activated carbon surface groups

\section{Introduction}

Małgorzata Wiśniewska

wisniewska@hektor.umcs.lublin.pl

1 Department of Radiochemistry and Environmental Chemistry, Faculty of Chemistry, Institute of Chemical Sciences, Maria Curie- Sklodowska University in Lublin, M. Curie-Sklodowska Sq. 3, 20-031 Lublin, Poland

2 Department of Physical Chemistry, Faculty of Chemistry, Institute of Chemical Sciences, Maria Curie- Sklodowska University in Lublin, M. Curie-Sklodowska Sq. 3, 20-031 Lublin, Poland

3 Depatrment of Applied Chemistry, Faculty of Chemistry, Adam Mickiewicz University in Poznań, Uniwersytetu Poznańskiego 8, 61-614 Poznan, Poland

4 Institute of Agrophysics Polish Academy of Sciences, Doświadczalna 4, 20-290 Lublin, Poland
The methods of the protein adsorption process examination on the solid surface are very diverse. These include: optical, spectroscopic, microscopic, and thermal analysis techniques. Using selected research methods, it is possible to determine, among others, biopolymer adsorbed amount, process kinetics, structural changes, and orientation of protein macromolecules. Each of these methods provides some information about the biopolymer adsorption mechanism or the structure of its adsorption layer which complements or confirms each other (Wiśniewska et al. 2018; 2020a). The advantage of thermal analysis methods combined with the mass spectrometry is that they enable the simultaneous study of the quantitative changes of adsorption (weight loss analysis) and specification of its mechanisms by determining the type of adsorbent surface groups (analysis of gaseous decomposition products). 
The simplest method of the protein adsorption study is the Solution Depletion Technique based on the determination of changes in the concentration of biopolymer in a solution due to its adsorption on the selected material surface. Protein concentration can be determined by various methods, e.g. based on UV absorption, fluorescence, colorimetry or radioisotope techniques (Jennisen 1981; Hlady et al. 1999). Several variations of this method have been developed, among which dynamic (chromatographic) and static methods have been distinguished. The first class of methods includes Saturating Sample-Load Column Method and Limited Sample-Load Column Method (Jennisen and Heilmeyer 1975; Jennisen and Demirolgou 1992). In the static methods (Batch Depletion Method: adsorption and Batch Repletion Method: desorption), adsorbed protein macromolecules are separated from those in the solution by centrifugation (Jennisen 1975; Jennisen and Botzet 1979). Radiolabeled proteins are often applied in their adsorption studies using autoradiography (Tollefen et al. 1971).

Ellipsometry, Variable Angle Reflectometry, Surface Plasmon Resonance are the most commonly used optical methods to study the process of protein adsorption. They are based on the interactions of light with the formed adsorption layer of biopolymer (Hlady et al. 1999). In Ellipsometry, linearly polarized light is reflected diagonally from the interface (determination of the optical properties of the surface which corresponds to the thickness of the adsorption layer (Thompson 1993)). Variable Angle Reflectometry is based on the measurements of refractive indices of the polarized light beam at the angles whose value is close to the Brewster angle (Schaaf et al. 1987). Surface Plasmon Resonance (SPR) is closely related to the surface plasmons, i.e. collective oscillations of free electrons on metallic surfaces which are dependent on the presence of protein adsorption layer (Kadir et al. 2005).

The spectroscopic methods, i.e. fluorescence spectroscopy (mainly total internal reflection fluorescence spectroscopy (TIRF)), infrared absorption (IR) spectroscopy (mainly Fourier transform infrared spectroscopy (FTIR)), Raman spectroscopy and circular dichroism (CD) Spectroscopy are based on the photons interactions with the adsorbed protein macromolecules (Buijs and Hlady 1997; Maiti et al. 2004; Smith and Dent 2005; Kęcki 2013). The intensity of the spectroscopic signal usually indicates the amount of protein adsorbed on the selected surface whereas the qualitative spectroscopic data provide information on the structure and conformation of biopolymer macromolecules.

Determination of the spatial distribution of protein macromolecules in the adsorption layer is more complicated and requires specialized equipment-high-resolution microscopes. Of the microscopic methods Atomic Force Microscopy (AFM), Scanning Optical Microscopy (SOM) (especially
Near-Field Scanning Optical Microscopy (NSOM) variant) are widely applied (Howland and Benatar 2002).

The thermal analysis methods (TG, DTG analysis, and DSC calorimetry coupled with analysis of gaseous products of thermal degradation using FTIR and QMS spectrometry) allow the determination of thermal decomposition of solid systems modified by the adsorption layers of selected biopolymers and characterization of adsorption mechanism of protein molecules (via the analysis of the type of solid surface groups and their possible interactions with the adsorbate macromolecules) (Wiśniewska et al. 2020b). Thermogravimetry (TG) is based on the changes in the sample mass during heating as a function of temperature. Differential Thermogravimetric Analysis (DTG) provides the information about the derivative of the TG data as a function of time which allows determination of the initial and final temperatures of the examined process. In turn, Differential Thermal Analysis (DTA) calorimetry characterizes the thermal behaviour of the sample during its physical and chemical changes as a function of time (Paulik 1995).

In the present study, the above-mentioned thermal analysis methods were used for the description of adsorption behaviour of selected proteins differing in internal stability (ovalbumin (OVA) and lysozyme (LSZ)) immobilised on the surface of activated biocarbon obtained from the horsetail herb precursor. They are a valuable complement to the adsorption, electrokinetic and aggregation data obtained for the systems described in our previous paper (Szewczuk-Karpisz et al. 2020). The previously performed experiments indicated that the mesoporous horsetail herb-based activated biocarbon exhibits the highest adsorption capacity related to OVA and LSZ at the protein isoelectric point (i.e. $\mathrm{pH} 5$ for OVA, $\mathrm{pH} 11$ for LSZ). Under the same conditions the most effective aggregation of solid suspension in the OVA and LSZ presence was observed (providing efficient removal of proteins from the aqueous solution using eco-friendly carbonaceous adsorbent). The data discussed in this paper indicated the types of biocarbon surface groups, enabling precise specification of the mechanism and strength of their interactions with the protein macromolecules. These results provided additional and valuable information which enable full characterization and understanding of the adsorption behaviour of the proteins at the activated carbonsolution interface. This contributes to more efficient and conscious planning of the technologies for the separation of undesirable nano-sized biopolymers in the water purification processes using nanostructured activated carbons.

\section{Experimental}

\section{Materials}

The examined activated carbon (AC) was obtained from the residue after extraction of the horsetail herb with 
ethanol using the procedure described in the previous paper (Szewczuk-Karpisz et al. 2020). The impregnated precursor with $50 \%$ phosphoric acid solution (weight $\mathrm{H}_{3} \mathrm{PO}_{4}$ : precursor ratio-2:1) was activated at $550{ }^{\circ} \mathrm{C}$ for $30 \mathrm{~min}$. The obtained material was characterized by the following textural parameters: the BET surface area$407 \mathrm{~m}^{2} / \mathrm{g}$, the total pore volume $-0.923 \mathrm{~cm}^{3} / \mathrm{g}$ and the average pore diameter-9.21 nm (sorptometer ASAP 2020, Micrometrics, Norcross US). The total content of the activated carbon surface groups was $2.32 \mathrm{mmol} / \mathrm{g}$, most of which $(2.28 \mathrm{mmol} / \mathrm{g})$ are the groups with acidic character (Boehm method Boehm (1994)).

Lysozyme (LSZ) and ovalbumin (OVA) were obtained from Sigma-Aldrich. Lysozyme is the enzymatic protein of cationic character, occurring mainly in polynuclear granulocytes, monocytes, and macrophages (in most tissue fluids such as tears, saliva). In turn, ovalbumin is a glycoprotein sourced from egg white belonging to the serpin family.

\section{Methods}

\section{Viscosity measurements}

Viscosity measurements were used for the hydrodynamic radius $\left(r_{\mathrm{h}}\right)$ determination of the both protein macromolecules at various $\mathrm{pH}$ values $(3,5$, and $11 \pm 0.1)$ at $25^{\circ} \mathrm{C}$. The $\mathrm{pH}$ values of the solutions were adjusted using $\mathrm{HCl}$ and $\mathrm{NaOH}$ with the concentrations $0.1 \mathrm{~mol} / \mathrm{dm}^{3}$ and $\mathrm{pH}$ meter (Beckman, Brea US). The measured viscosities $(\eta)$ were converted to the reduced viscosities $\left(\eta_{\text {red }}\right)$ according to the equation:

$\eta_{\text {red }}=\frac{\eta_{s p}}{c}=\frac{\eta_{r e l}-1}{c}=\frac{\frac{\eta_{1}}{\eta_{0}}-1}{c}$

where $\eta_{\mathrm{sp}}$ specific viscosity, $\eta_{\text {rel }}$ relative viscosity, $\eta_{0}$ supporting electrolyte solution viscosity, $\eta$ protein viscosity in the supporting electrolyte solution, $c$ protein concentration in the supporting electrolyte solution.

The concentrations of the biopolymer in the supporting electrolyte solution $(\mathrm{NaCl}$ with the concentration $0.001 \mathrm{~mol} / \mathrm{dm}^{3}$ ) ranged from 10 to $500 \mathrm{ppm}$.

Using the linear dependence of the reduced viscosity as a function of the protein concentration, the intrinsic viscosity $[\eta]$ was determined by extrapolating the obtained line to a concentration equal to 0 :

$[\eta]=\lim _{c \rightarrow 0}\left(\eta_{\text {red }}\right)$

Hydrodynamic radius $\left(\underline{r}_{\mathrm{h}}\right)$ of the lysozyme and ovalbumin macromolecules was calculated using the formula developed by Einstein-Simha (Armstrong et al. 2004): $r_{h}=\sqrt[3]{\frac{[\eta] 3 M}{10 \pi N_{A}}}$

where $M$ protein molecular weight, $N_{A}$ Avogadro number.

The viscosity of the biopolymer solutions was determined using a rotary rheometer CVO 50 (Bohlin Instruments, Worcestershire UK), which was cooperating with a thermostat RTE 111 M (Spectro-Lab, Warsaw Poland). The measuring system of this apparatus is composed two coaxial cylinders made of stainless steel. The double gap obtained in this way guarantees high sensitivity of measurements, resulting from the large surface area of the working system.

\section{Adsorption and electrokinetic measurements}

Adsorption and electrokinetic measurements were performed in the presence of the supporting electrolyte- $-\mathrm{NaCl}$ with the concentration $0.001 \mathrm{~mol} / \mathrm{dm}^{3}$ at $25^{\circ} \mathrm{C}$.

The protein adsorbed amount on the activated carbon surface was determined using the static method based on the difference in its concentration in the solution before and after the adsorption process. The protein concentration was established spectrophotometrically (spectrophotometer UV/Vis, Jasco-530, Tokyo Japan) at the wavelength $280 \mathrm{~nm}$ (maximum UV absorbance).

The potentiometric titration method allowed the determination of the surface charge density of the solid systems (without and with ovalbumin or lysozyme) as well as their $\mathrm{pH}_{\mathrm{pzc}}$ value (pzc - point of zero charge). On the other hand, electrophoretic mobility measurements (zetameter Nano ZS, Malvern Instruments, Bristol UK) allowed the determination of zeta potential of the AC suspensions (without and with adsorbates) as well as their $\mathrm{pH}_{\text {iep }}$ values (iep-isoelectric point). The detailed presentation of the obtained results was given in our previous paper (Szewczuk-Karpisz et al. 2020), and this paper presents some results relevant to viscosity and thermal data analysis (obtained for the initial concentration of biopolymers $500 \mathrm{ppm}$ and $\mathrm{pH}$ values: 3,5 and $11 \pm 0.1$ ).

\section{Thermal measurements}

Thermal properties of the samples were determined using the simultaneous thermal analyzer STA 449 F1 Jupiter (Netzsch, Selb Germany). The TG, differential TG (DTG) and differential scanning calorimetry (DSC) curves were recorded over the $30-950{ }^{\circ} \mathrm{C}$ range at a heating rate of $10{ }^{\circ} \mathrm{C} / \mathrm{min}$ in the helium and synthetic air atmosphere $(50 \mathrm{~mL} / \mathrm{min})$ using a TGA-DSC sensor type S. In order to determine the oxygen groups on the surface of unmodified active carbon, the measurements in helium were performed at up to $1200{ }^{\circ} \mathrm{C}$. The samples: mass $\sim 10 \mathrm{mg}$ (in helium atmosphere) and mass $\sim 7 \mathrm{mg}$ (in air atmosphere) were placed in the alumina

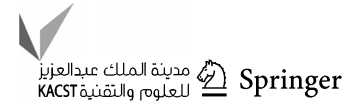


crucible. The empty $\mathrm{Al}_{2} \mathrm{O}_{3}$ crucible was used as a reference. The gaseous products emitted during decomposition of the materials were analysed by the FTIR spectrometer Tensor 27 (Brucker Optik GmbH, Ettlingen Germany) and by QMS 403D Aeölos (Netzsch, Selb Germany) coupling on-line to the thermal analyzer. The data were collected and processed using the NETZSCH Proteus ${ }^{\circledR}$ software, version 6.1.

The probes for thermal measurements were prepared at $25^{\circ} \mathrm{C}$ in the same way as for the adsorption measurements. $0.01 \mathrm{~g}$ of the activated carbon was added to $10 \mathrm{~cm}^{3}$ of the solution containing the supporting electrolyte $(0.001 \mathrm{~mol} /$ $\mathrm{dm}^{3} \mathrm{NaCl}$ ) and selected protein (ovalbumin or lysozyme with the concentration $500 \mathrm{ppm}$ ). Then the $\mathrm{pH}$ of the samples was adjusted to the value 3,5 , or $11 \pm 0.1$. When the adsorption was complete, the solid was separated from the solution using the micro-centrifuge, dried at room temperature and subjected to the thermal measurements.

\section{Results and discussion}

The size of protein macromolecules in the solutions of different $\mathrm{pH}$ values depends on their internal stability. Both proteins differ from each other as regards physicochemical parameters such the pI (isoelectric point) value and molecular weight, as well as internal stability (Rabe et al. 2011). LSZ is classified as a 'hard protein'-it has high internal stability, that is its conformation is slightly dependent on the solution $\mathrm{pH}$ value. In turn, OVA is a 'soft protein'-it has low internal stability and assumes denatured conformations in the solutions of strongly acidic or basic character. The isoelectric point (pI) of ovalbumin is about 4.8 whereas that of lysozyme-about 10.7 (Szewczuk-Karpisz et al. 2020). The molecular weight of LSZ is $14.3 \mathrm{kDa}$ whereas that of OVA is $43 \mathrm{kDa}$. Figure 1 shows the dependencies of the reduced viscosities of ovalbumin and lysozyme solutions as a function of protein concentration obtained at different $\mathrm{pH}$ values. In turn, Table 1 presents the values of hydrodynamic radius of protein macromolecules determined from the intrinsic viscosities data.

Proteins with low internal stability, such as OVA, undergo strong structural changes at $\mathrm{pH}$ values close to their isoelectric point. This is directly related to their denaturation which manifests itself in the destruction of the secondary, tertiary, and quaternary structures resulting from the breaking of the stabilizing chemical bonds (hydrogen, ionic, and disulfide bridges). It is worth noting, that at $\mathrm{pH}$, which is close to the isoelectric point OVA, the protein assumes its native structure and its size is the smallest-the hydrodynamic radius is $2.76 \mathrm{~nm}$. This is consistent with the literature data which state that the diameter of the OVA particle varies in the range of 5.4-5.6 nm (Nakamura et al. 1997; Neumann et al.2010). Clear denaturation of albumin macromolecules
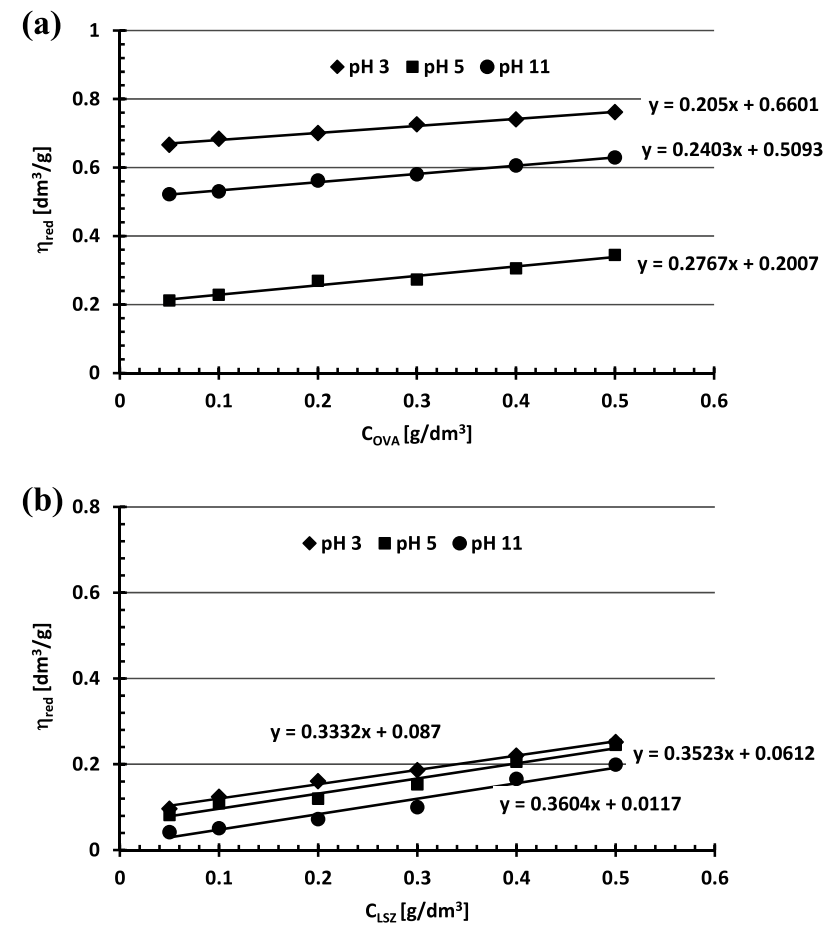

Fig. 1 Dependencies of the reduced viscosity of OVA (a) and LSZ (b) solutions on their concentration at $\mathrm{pH} 3,5$ and 11

Table 1 Characteristics of protein macromolecule sizes in the solution

\begin{tabular}{lrll}
\hline Protein & $\mathrm{pH}$ & $\begin{array}{l}{[\eta]} \\
{\left[\mathrm{dm}^{3} / \mathrm{g}\right]}\end{array}$ & $\begin{array}{l}\mathrm{r}_{\mathrm{h}} \\
{[\mathrm{nm}]}\end{array}$ \\
\hline OVA & 3 & 0.6601 & 4.10 \\
& 5 & 0.2007 & 2.76 \\
& 11 & 0.5093 & 3.76 \\
LSZ & 3 & 0.0870 & 2.09 \\
& 5 & 0.0612 & 1.86 \\
& 11 & 0.0117 & 1.07 \\
\hline
\end{tabular}

occurs only at $\mathrm{pH} 3$ and 11 . Under these conditions, the $r_{\mathrm{h}}$ of ovalbumin is 4.1 and $3.76 \mathrm{~nm}$, respectively (Table 1). Therefore, the extent of development of the ovalbumin macromolecules is the greatest in the solution of $\mathrm{pH} 3$.

On the other hand, the structure of high internal stability proteins including lysozyme, is slightly dependent on the solution $\mathrm{pH}$. This indicates that their macromolecules retain their native conformation within the wide $\mathrm{pH}$ range. According to the literature reports, lysozyme does not change its structure in the $\mathrm{pH}$ range 1-8 (Parmar et al. 2009). This is confirmed by the viscosity measurement results, i.e. the values of the hydrodynamic radius of LSZ macromolecules in the solution. In the range up to $\mathrm{pH} 9$, no significant changes in the values of this parameter were observed. It varies from $2.09(\mathrm{pH} \mathrm{3)}$ to $1.86 \mathrm{~nm}(\mathrm{pH} 9)$. Only at $\mathrm{pH} \mathrm{11,} \mathrm{which} \mathrm{is}$ very close to the value of the isoelectric point of lysozyme, 
the size of its macromolecules decreases noticeably and $r_{\mathrm{h}}$ reaches the value of $1.07 \mathrm{~nm}$.

The $\mathrm{pH}_{\mathrm{pzc}}$ value of the activated carbon without adsorbates is 3.2 (Fig. 2a). Thus, at pH 3.2 its surface charge is equal to 0 . Such a small acidic value of pzc results from a large content of surface oxygen groups with acidic character in comparison to those with basic one. The protein addition changes noticeably the position of $\mathrm{pH}_{\mathrm{pzc}}$ points (they were shifted towards higher $\mathrm{pH}$ values, changing in the range 3.7-3.9). According to Hartvig et al. (2011) the changes in the solid surface charge are mainly dependent on the type of amino acids that are close to the surface (N-terminus and the side chains of arginine, histidine and lysine of the adsorbed amino acids, as well as the C-terminus and aspartate, glutamate, cysteine and tyrosine amino acid side chains).

In turn, the isoelectric point of the activated carbon $\left(\mathrm{pH}_{\text {iep }}\right)$ is 2.4 (Fig. 2a). The protein addition contributes to a clear shift of the solid $\mathrm{pH}_{\mathrm{iep}}$ value. In the case of both examined proteins, the observed $\mathrm{pH}_{\text {iep }}$ value of solid particles covered with the biopolymer approaches the $\mathrm{pI}$ value of the protein. In the presence of OVA, the $\mathrm{pH}_{\text {iep }}$ value is about 4.9

(a)

\section{$\mathrm{pH}$ values corresponding with pzc and iep points}

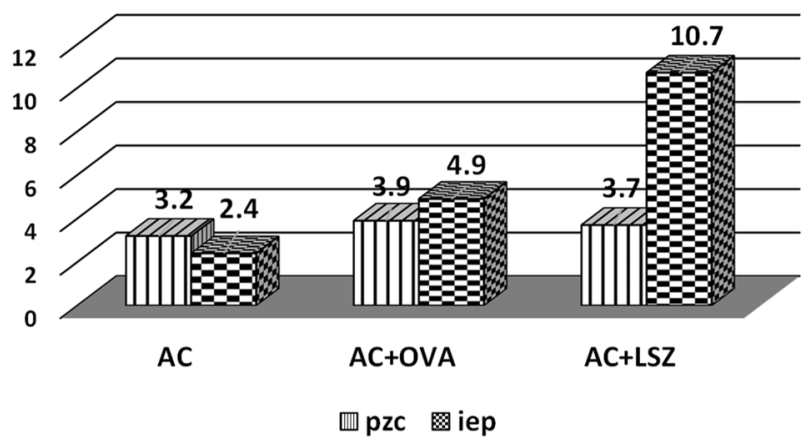

(b)

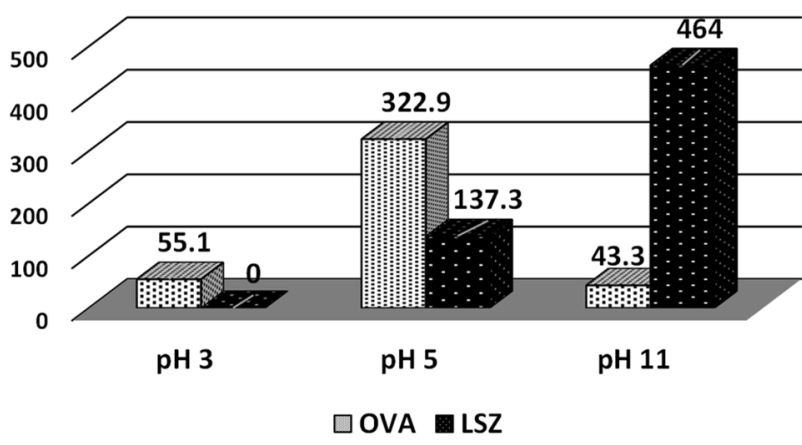

Fig. 2 Electrokinetic parameters characterizing the AC systems without and with adsorbed proteins (a) and the protein adsorbed amounts on the AC surface at $\mathrm{pH} \mathrm{3,5}$ and 11 (b); the initial concentration of the biopolymer equal to $500 \mathrm{ppm}$ whereas in the presence of LSZ it is 10.7. Such behaviour ensures the total coverage of the solid surface by the protein macromolecules - as a consequence of their adsorption, the solid acquires properties similar to those of the adsorbate (Rezwan et al. 2005; Szewczuk-Karpisz and Wiśniewska 2014).

As can be seen in Fig. 2b the greatest adsorption of proteins on the activated carbon surface occurs at such a $\mathrm{pH}$ value which is very close to the $\mathrm{pI}$ value of the specific biopolymer. Thus, for OVA its maximal adsorption is observed at pH 5 (about $322 \mathrm{mg} / \mathrm{g}$ ) whereas for LSZ the highest adsorption level is obtained at pH 11 (about $464 \mathrm{mg} / \mathrm{g}$ ). Under these conditions proteins macromolecules have a net charge equal to 0 - there is no electrostatic repulsion between the molecules adsorbed on the AC surface (Pezennec et al. 2000) and the protein desorption is minimal. What is more, at $\mathrm{pH} 5$ the OVA molecules $\left(r_{\mathrm{h}}\right.$ is $2.76 \mathrm{~nm}$ ) can penetrate freely the mesopores (with the diameter $9.21 \mathrm{~nm}$ ) present in the engineered biochar structure. In the case of LSZ at pH $11\left(r_{\mathrm{h}}\right.$ is $\left.1.07 \mathrm{~nm}\right)$, such penetration is much more effective and the lysozyme adsorption reaches the highest level of all examined systems.

Figure 3a shows the thermoanalytical curves obtained as a result of the thermal decomposition of the activated carbon in the helium atmosphere. In the first stage, up to $150{ }^{\circ} \mathrm{C}$, the weight loss of $0.82 \%$ is related to the endothermic process of physically bound water removal from the AC surface. At higher temperatures, the presence of peaks on the DTG and Gram Schmidt curves with the weight losses: $0.97 \%$ at $150-450{ }^{\circ} \mathrm{C}, 6.65 \%$ at $450-800{ }^{\circ} \mathrm{C}$ and $32.71 \%$ at $800-1200{ }^{\circ} \mathrm{C}$ is related to the decomposition of the surface oxygen groups. For better interpretation of these results, Fig. 3 presents the changes in the intensity of the carbon monoxide signals as a function of temperature obtained from the analysis of gaseous products of reaction by means of the infrared spectroscopy method. Comparing the obtained results with the literature data (Figueiredo et al. 1999; Szymański et al. 2002; Sternik et al. 2019), it can be concluded that in the first stage the carboxylic groups are destroyed which causes $\mathrm{CO}_{2}$ emission (Fig. 4), and in the second stage-mainly lactone groups (emission of $\mathrm{CO}_{2}$ ) and additionally carboxylic $\left(\mathrm{CO}_{2}\right.$ and $\mathrm{CO}$ emissions) and phenolic (CO emission) anhydrides. Above the temperature of $800{ }^{\circ} \mathrm{C}$, the increase in the intensity of $\mathrm{CO}$ and $\mathrm{CO}_{2}$ signals in the gaseous products indicates clearly the decomposition of carbonyl, quinone and pyron groups. Our previous study (Wiśniewska et al. 2017; Sternik et al. 2019) shows that the concentration and type of surface groups of activated carbons depend largely on the type of precursor substrate, as well as carbon material synthesis and activation methods. Figures $3 b$ and $c$ show the TG-DTG-DSC curves of carbon biocomposites modified by proteins in the solutions of $\mathrm{pH}$ 5 (for OVA) and $\mathrm{pH} 11$ (for LSZ). As in the case of the 
Fig. 3 TG, DTG and DSC curves in helium of AC unmodified (a) and modified with proteins: OVA (b) at $\mathrm{pH} 5$ and LSZ (c) at $\mathrm{pH} 11$ (a)

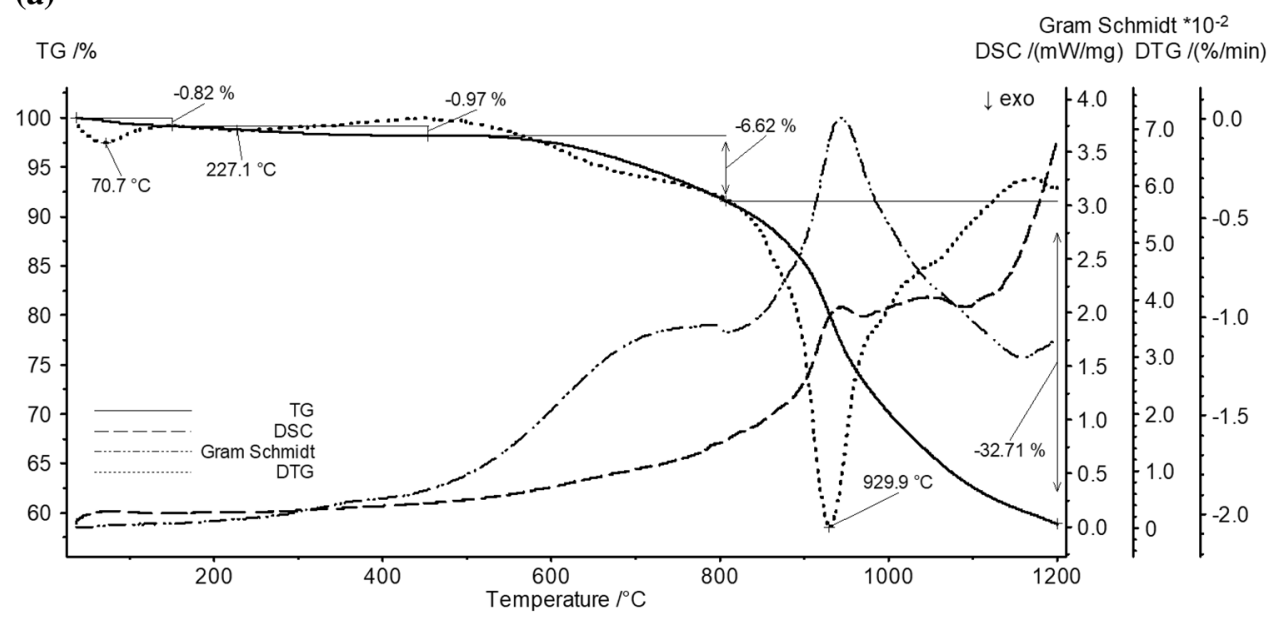

(b)

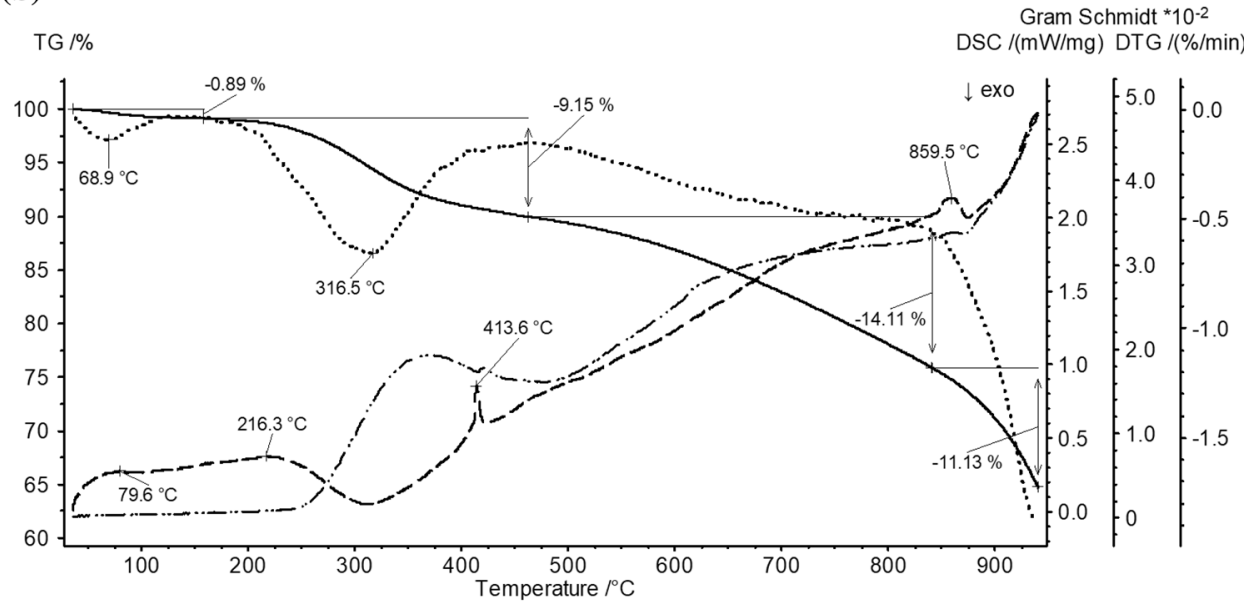

(c)

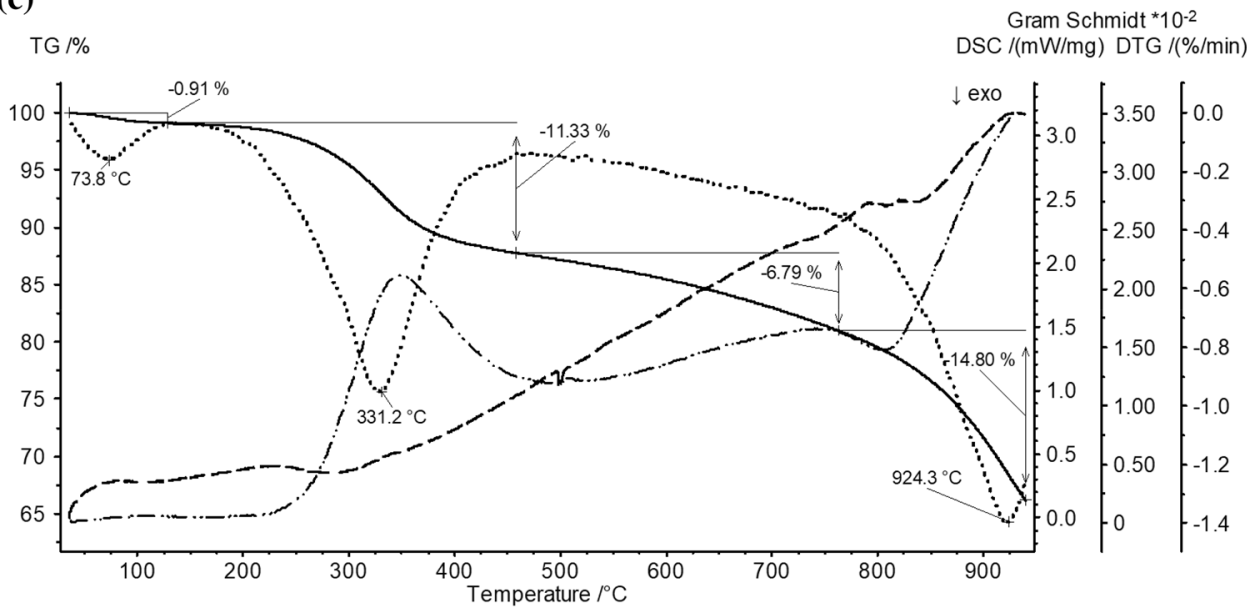

unmodified AC sample at low temperatures, the first endothermic process at temperatures up to $125^{\circ} \mathrm{C}$ with the weight losses below $1 \%$ is associated with the dehydration process. In the second stage, in the temperature range of $150-450{ }^{\circ} \mathrm{C}$, wide peaks on the DTG curves with weight losses of $9.15 \%$ $\left(\mathrm{T}_{\mathrm{DTG}}=316.5^{\circ} \mathrm{C}\right)$ and $11.33 \%\left(\mathrm{~T}_{\mathrm{DTG}}=331.2{ }^{\circ} \mathrm{C}\right)$ for the
$\mathrm{AC}+\mathrm{OVA}$ sample (at $\mathrm{pH} 5$ ) and $\mathrm{AC}+\mathrm{LSZ}$ one (at $\mathrm{pH} 11$ ) are mainly related to the condensation, decarboxylation, and deamination of individual amino acids of the proteins (Dunn and Brophy 1932; Kato and Fujimaki 1971; Yablokov et al. 2013; Weiss et al. 2018). According to the literature data (Kuzema et al. 2016; Chrzanowska and Deryło-Marczewska 


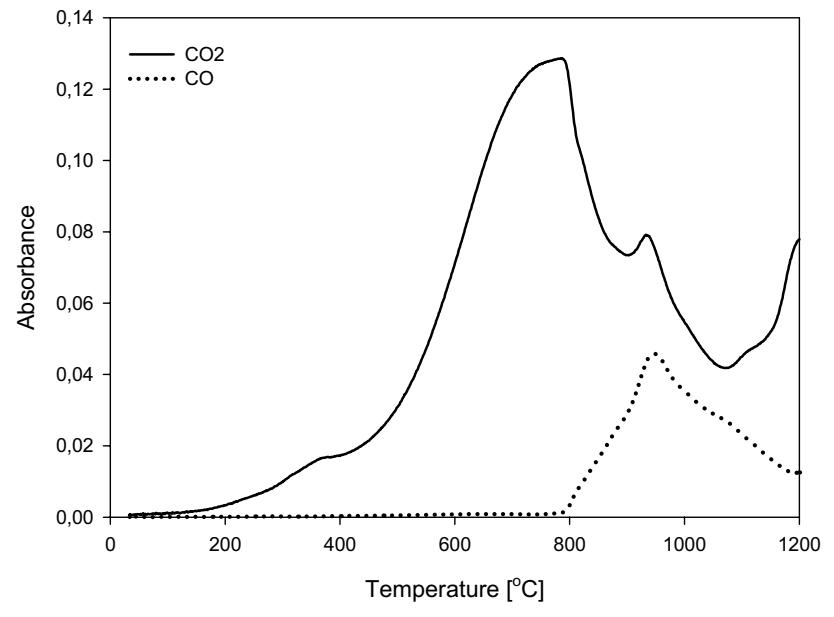

Fig. 4 Changes in signal intensity of a) $\mathrm{CO}_{2}$ and b) $\mathrm{CO}$ determined from the FTIR analysis during pyrolysis of unmodified activated carbon

2019) the main products of protein decomposition are: $\mathrm{H}_{2} \mathrm{O}, \mathrm{NH}_{3}, \mathrm{HCN}, \mathrm{C}_{2} \mathrm{H}_{4}, \mathrm{CO}_{2}$ and $\mathrm{CH}_{4}$, as well as ketones, aldehydes, carboxylic acids and other hydrocarbons can be formed. The MS spectra of the main decomposition products of the analyzed carbon biocomposites are presented in Fig. 5. In the discussed temperature range to $500{ }^{\circ} \mathrm{C}$, there appear the sharp peaks originating from $\mathrm{m} / \mathrm{z}: 15\left(\mathrm{CH}_{4}\right), 17$ $\left(\mathrm{H}_{2} \mathrm{O}, \mathrm{NH}_{3}\right), 18\left(\mathrm{H}_{2} \mathrm{O}\right), 27(\mathrm{HCN}), 30(\mathrm{NO}), 41\left(\mathrm{CH}_{3} \mathrm{CN}\right)$, $44\left(\mathrm{CO}_{2}\right), 51$ (alkyl radicals) as well as slight peaks for 46 $\left(\mathrm{NO}_{2}, \mathrm{CO}_{2}\right), 64\left(\mathrm{SO}_{2}\right), 78$ and 91 (aromatic compounds), which are absent in the MS spectrum of the unmodified AC sample. In addition, in the case of the AC + LSZ sample (at $\mathrm{pH} 11$ ), $\mathrm{H}_{2} \mathrm{~S}$ was formed during pyrolysis (Fig. 5f). In the case of the LSZ modified sample, an increase in the intensity of the peaks in relation to the OVA modified one was observed. Additionally, the shift of peaks position on the DTG and most MS curves towards higher temperatures takes place, which is related to the greater amount of adsorbed protein. Above $450{ }^{\circ} \mathrm{C}$, endothermic effects with the weight loss of $25.24 \%$ (AC+ OVA at pH 5) and 21.59\% (AC+ LSZ at $\mathrm{pH} 11)$ are mainly related to the further decomposition of biopolymer residues strongly bound to the adsorbent surface and inside its pores, as well as oxygen groups of carbon surface as a result of decarbonization. These processes take place in a continuous manner in the whole discussed temperature range and the main gaseous products of decomposition are $\mathrm{CO}_{2}$ (Fig. 5h) and nitrogen oxides (Fig. 5e).

The decomposition processes during heating depend primarily on the amount of adsorbed adsorbate, the pore structure, and the functional groups of the activated carbon. Figures 6 and 7 show the TG, DTG IDSC curves of thermal decomposition in the atmosphere of synthetic air obtained for the samples of unmodified activated carbon

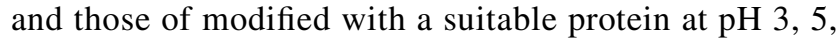
and 11 . In the case of unmodified activated carbon, two main stages can be observed. The first one, with a weight loss of approx. $0.9 \%$, is related to the dehydration process. In the temperature range of $150-940{ }^{\circ} \mathrm{C}$, there is a distinct exothermic peak on the DTG and DSC curves, which reflects the oxidation process taking place in the samples. This process may be multi-stage, depending on the conditions of its conduction, as mentioned in our previous papers (Skowroński 1979; Deryło-Marczewska et al. 2010). The main decomposition products were $\mathrm{CO}_{2}(\mathrm{~m} / \mathrm{z}$ 44) and $\mathrm{H}_{2} \mathrm{O}(\mathrm{m} / \mathrm{z}$ 18) (Fig. 8). In addition, the occurrence of nitrogen oxides $(\mathrm{m} / \mathrm{z}, 30)$ and $\mathrm{SO}_{2}(\mathrm{~m} / \mathrm{z} 64)$ in gaseous products, prove the presence of sulfur and nitrogen groups on the AC surface. For the OVA and LSZ modified samples, the first stage (up to $150{ }^{\circ} \mathrm{C}$ ) associated with the dehydration, is not much different from starting material. A slight increase in the weight loss by approx. $0.3 \%$ and the shift of DTG peaks towards higher temperatures is related to additional interactions of water molecules with the functional groups of amino acids included in individual proteins. Evident changes were observed in the temperature range of $200-450{ }^{\circ} \mathrm{C}$. Weight losses from 4.4 to $9 \%$ for the OVA modified samples and from 4.6 to $12 \%$ for the LSZ modified samples are the result of organic substances decomposition processes. As in the case of the previously discussed measurements in helium, in this temperature range, there are processes related to decarboxylation and deamination of amino acids adsorbed on the adsorbent surface as well as partial oxidation of carbon biocomposites. As a result, the total energy effect of the reaction is exothermic, and the increase in its intensity for $\mathrm{AC}+\mathrm{OVA}$ pH 5 and AC + LSZ pH 11 samples results from a significant increase in the surface concentration of the protein due to its maximal adsorption under the $\mathrm{pH}$ conditions close to the isoelectric point of the biopolymer (Figs. 6 and 7). As can be seen from the MS data presented in Fig. 8, the main products of amino acid degradation were $\mathrm{HCN}(\mathrm{m} / \mathrm{z} 27), \mathrm{CH}_{3} \mathrm{CN}(\mathrm{m} / \mathrm{z} 41), \mathrm{NH}_{3}(\mathrm{~m} / \mathrm{z}, 17)$, hydrocarbons $(\mathrm{m} / z 51,15)$, benzene $(\mathrm{m} / z \mathrm{78})$ and oxides formed as a result of oxidation of organic molecules and carbon surface groups: $\mathrm{H}_{2} \mathrm{O}(\mathrm{m} / \mathrm{z} 18) ; \mathrm{CO}_{2}(\mathrm{~m} / \mathrm{z} 44), \mathrm{NO}_{2}(\mathrm{~m} / \mathrm{z}$ $30,46)$ and $\mathrm{SO}_{2}(\mathrm{~m} / z$ 64). Similar to the unmodified $\mathrm{AC}$ sample, the main decomposition stages took place in the $400-700{ }^{\circ} \mathrm{C}$ temperature range. Weight losses over $54 \%$ are mainly related to the oxidation of organic nitrogen, carbon materials formed as a result of the decomposition of biopolymers and $\mathrm{AC}$ graphene layers. As a result of these reactions, the evolution of $\mathrm{CO}_{2}, \mathrm{NO}_{2}, \mathrm{H}_{2} \mathrm{O}$, and $\mathrm{SO}_{2}$ was observed in the mixture of post-reaction gases, but in the case of the latter two, the intensity of the release was lower than in the previously discussed stage.

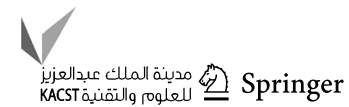


Fig. 5 Evolution of MS signals of main gaseous products $\mathbf{a} \mathrm{m} / \mathrm{z}$ $15\left(\mathrm{CH}_{4}\right)$; b $17\left(\mathrm{H}_{2} \mathrm{O}, \mathrm{NH}_{3}\right)$; c $18\left(\mathrm{H}_{2} \mathrm{O}\right)$; d $27(\mathrm{HCN})$, e 30 $\left(\mathrm{NO}, \mathrm{NO}_{2}\right), \mathbf{f} 34\left(\mathrm{H}_{2} \mathrm{~S}\right), \mathbf{g} 41$ $\left(\mathrm{CH}_{3} \mathrm{CN}\right), \mathbf{h} 44\left(\mathrm{CO}_{2}\right), \mathbf{i} 46$ $\left(\mathrm{NO}_{2}, \mathrm{CO}_{2}\right), \mathbf{j} 51$ (alkyl radicals), k $64\left(\mathrm{SO}_{2}\right)$ as well as aromatic compounds: $m / z 78$ (k) and 91 (l) of pyrolysis in the helium of AC unmodified (black line) and modified with OVA (circle) and LSZ (star) at pH 5 and 11, respectively
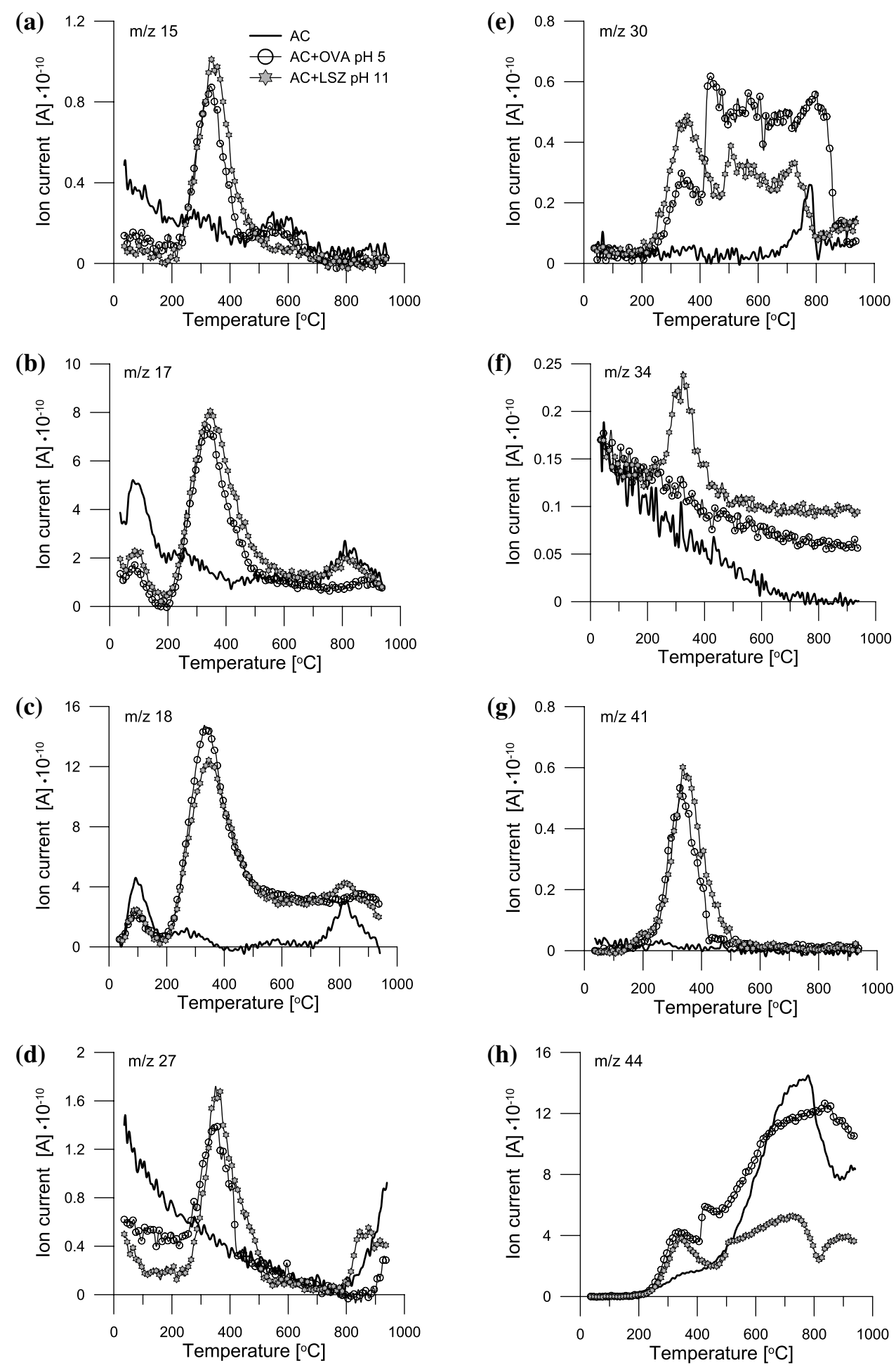

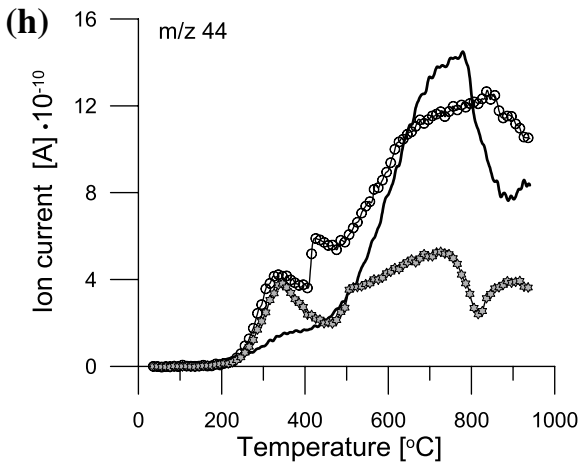


Fig. 5 (continued)
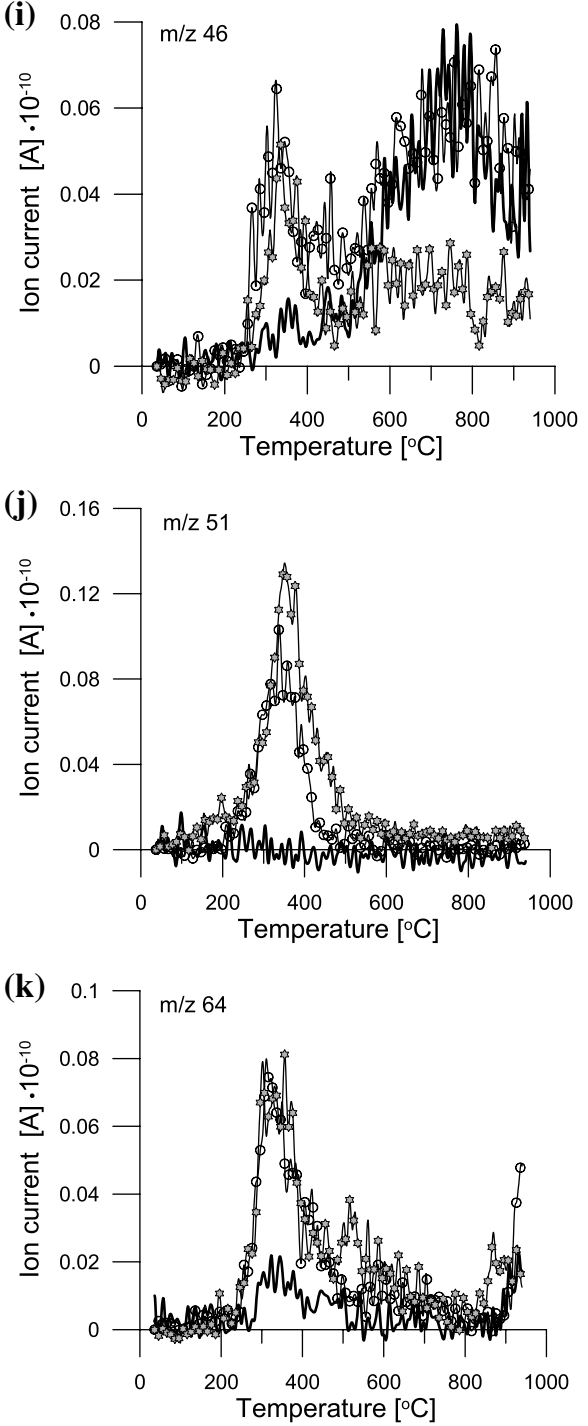
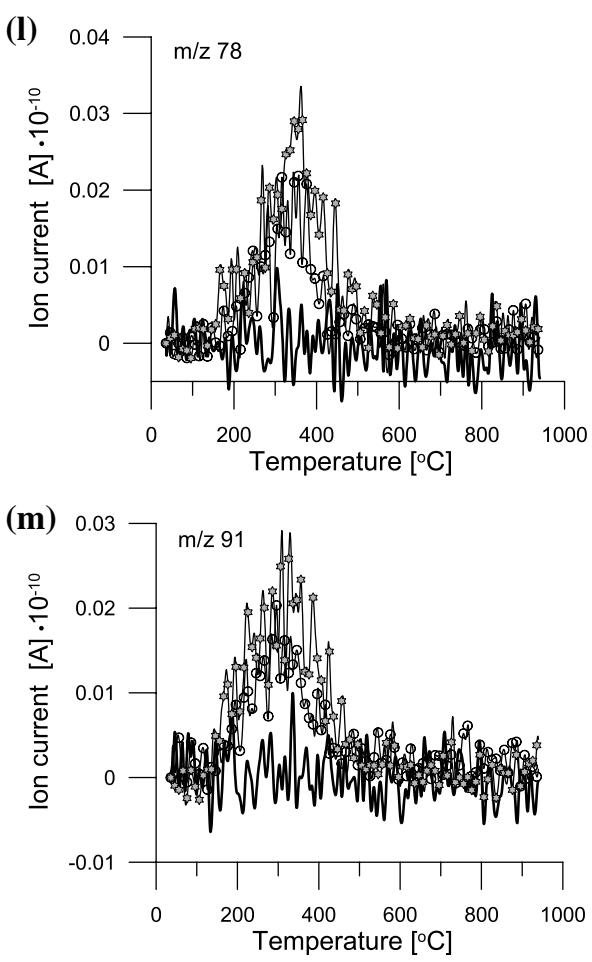

\section{Conclusions}

The smallest sizes of both biopolymers macromolecules under the $\mathrm{pH}$ conditions very close to their isoelectric points ( $\mathrm{pH} 5$ for OVA and $\mathrm{pH} 11$ for LSZ) enable free penetration of proteins into the solid pores. This results in the highest adsorption level of both proteins at $\mathrm{pHs}$ corresponding with their $\mathrm{pI}$ points. This is also the main reason for the greatest changes in the weight losses of the AC+OVA (prepared at
$\mathrm{pH}$ 5) and $\mathrm{AC}+\mathrm{LSZ}$ (prepared at $\mathrm{pH} 11$ ) systems during their thermal decomposition in relation to the unmodified activated biocarbon. The MS spectra analysis indicated that the main decomposition products of the activated carbon/ protein composites are $\mathrm{CH}_{4}, \mathrm{H}_{2} \mathrm{O}, \mathrm{NH}_{3}, \mathrm{HCN}, \mathrm{NO}, \mathrm{CH}_{3} \mathrm{CN}$, $\mathrm{CO}_{2}$, alkyl radicals, $\mathrm{NO}_{2}, \mathrm{SO}_{2}$ and aromatic compounds. Their presence is the result of oxidation reactions of organic nitrogen, carbon materials formed during the decomposition of biopolymers and graphene layers of activated carbon. 
Fig. 6 TG (a), DTG (b) and DSC (c) curves in the air atmosphere of AC unmodified and modified with OVA; modifications were performed at $\mathrm{pH} 3,5$ and 11 for the initial concentration of the biopolymer equal to $500 \mathrm{ppm}$ (a)

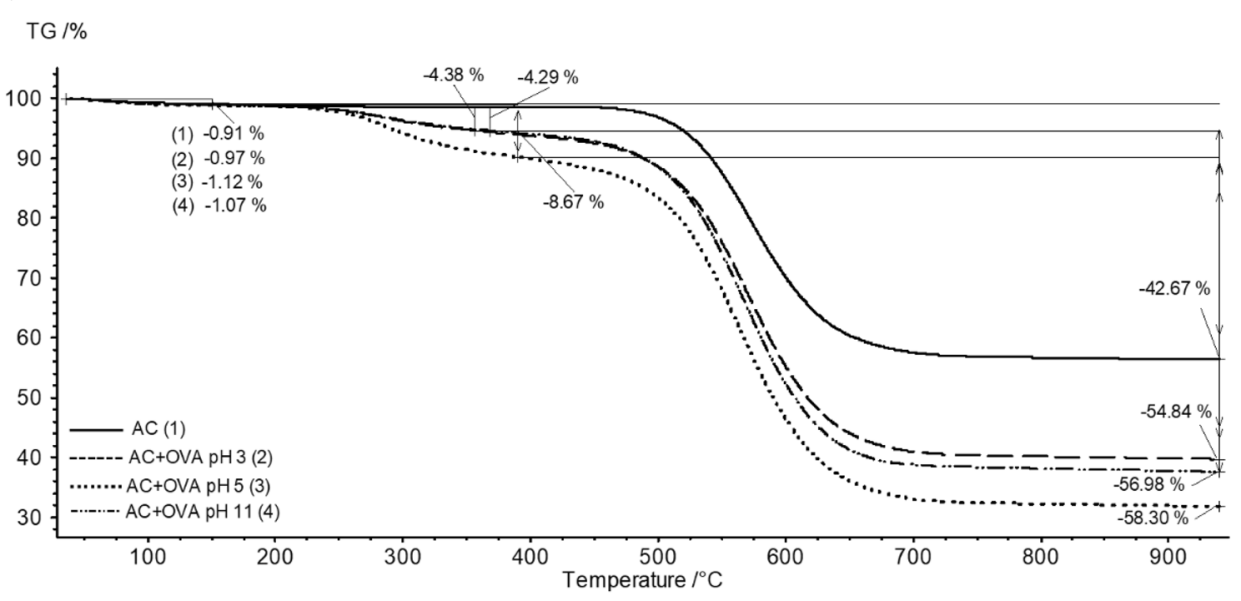

(b)

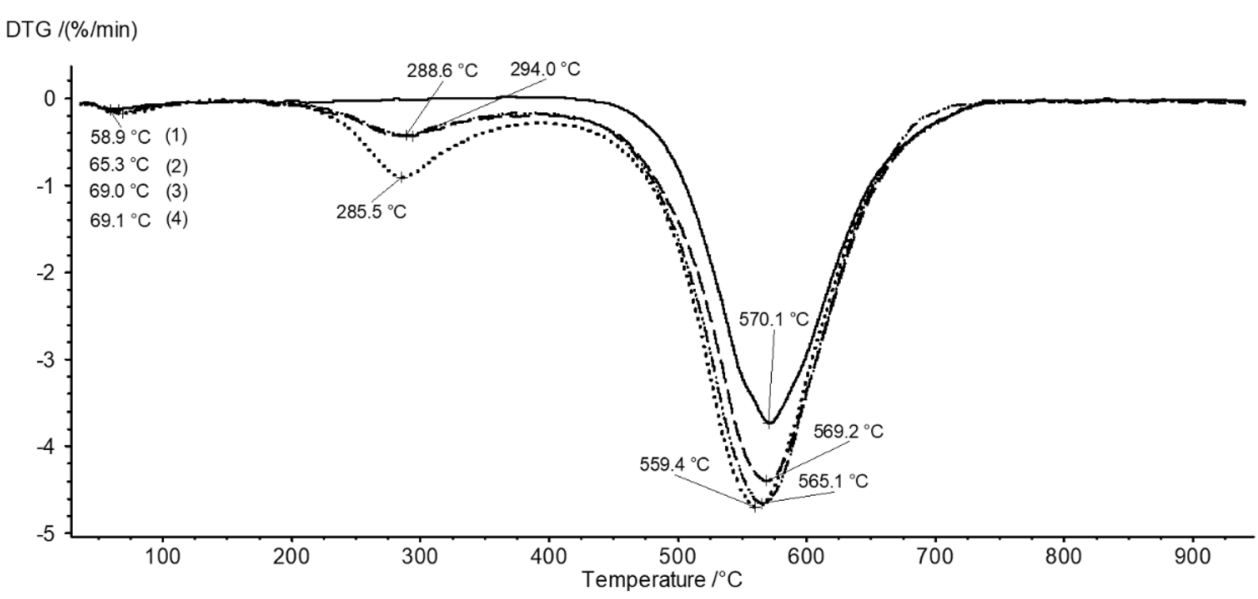

(c)

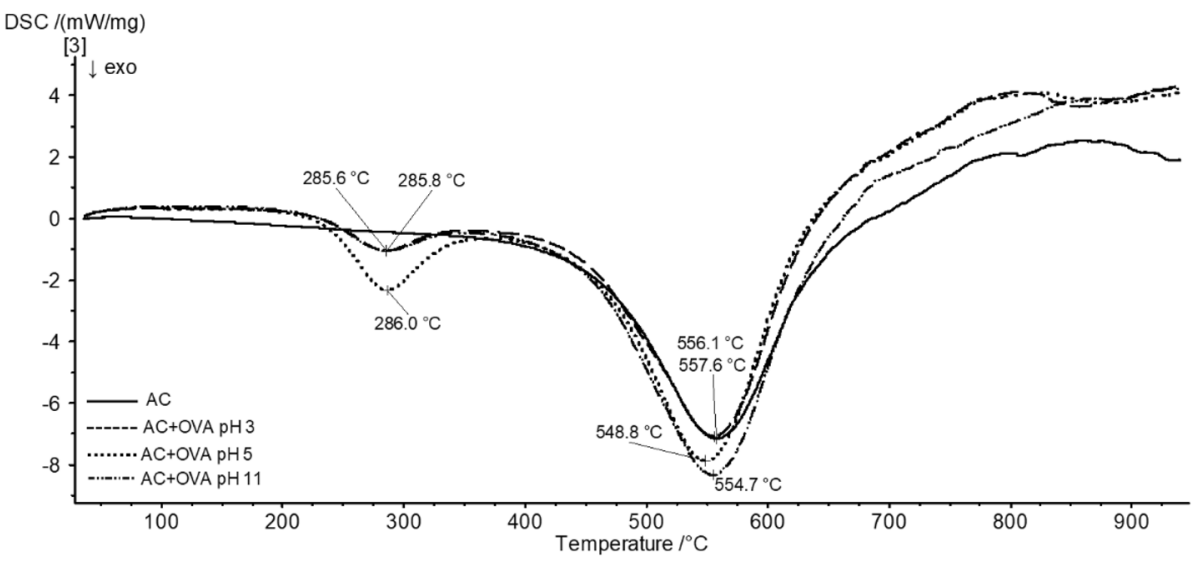


Fig. 7 TG (a), DTG (b) and DSC (c) curves in the air atmosphere of AC unmodified and modified with LSZ; modifications were performed at $\mathrm{pH} 3,5$ and 11 for the initial concentration of the biopolymer equal to $500 \mathrm{ppm}$ (a)

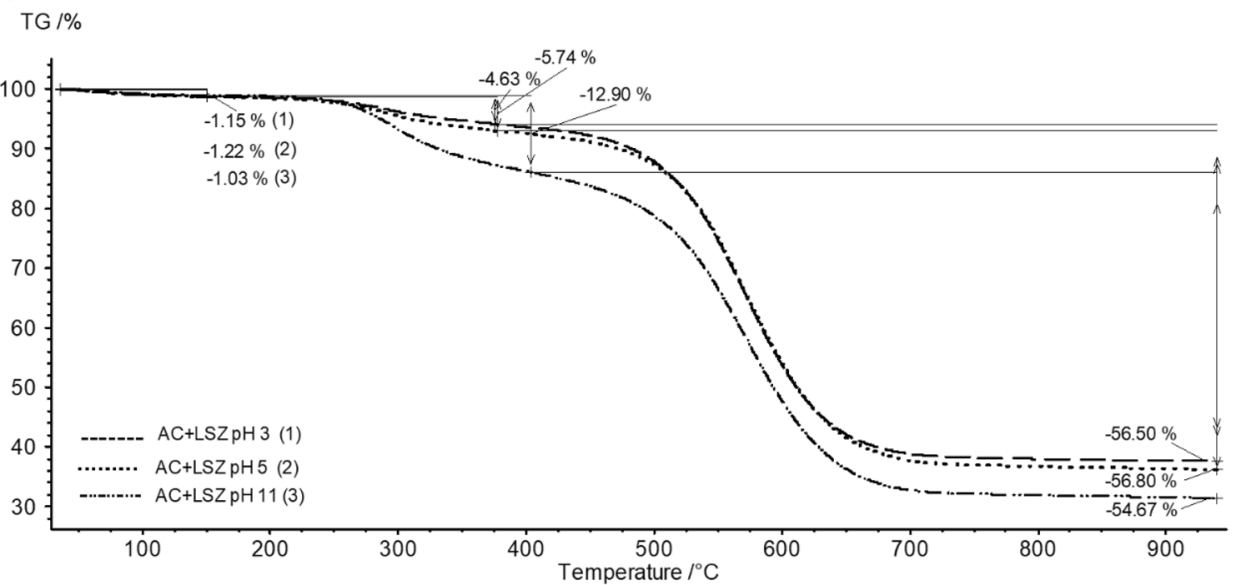

(b)

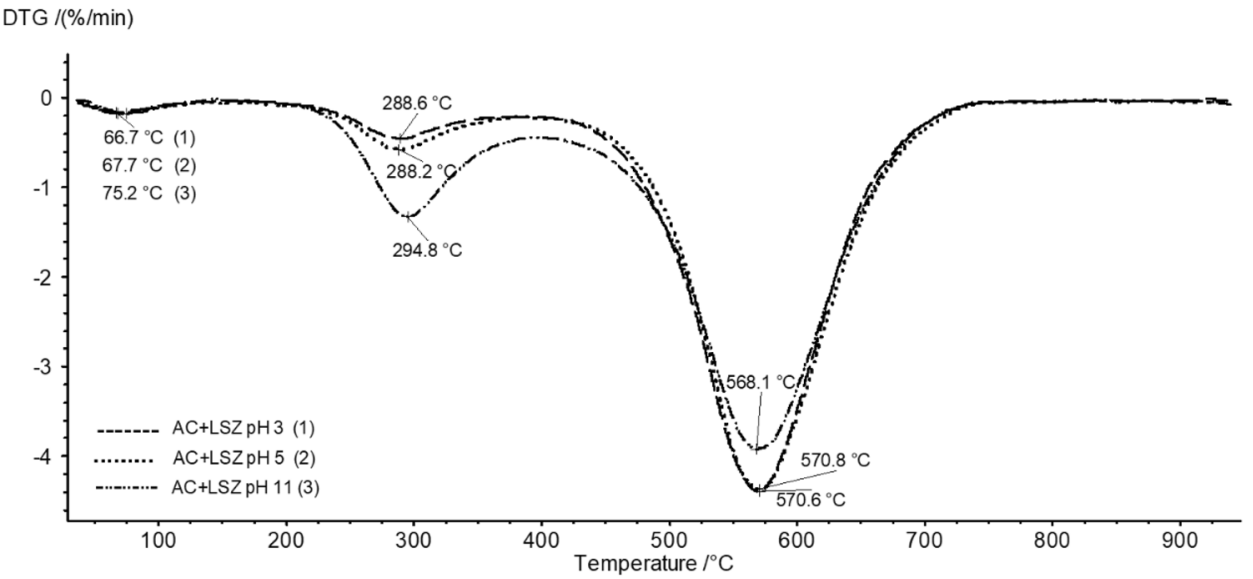

(c)

$\mathrm{DSC} /(\mathrm{mW} / \mathrm{mg})$

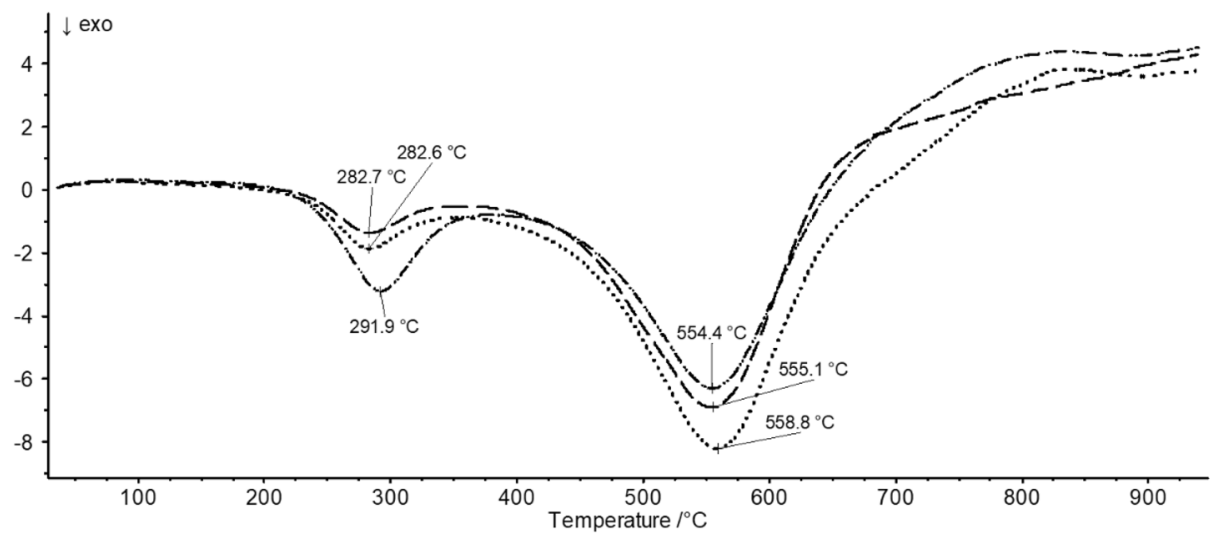


Fig. 8 Evolution of MS signals of main gaseous products a $\mathrm{m} / \mathrm{z} 15\left(\mathrm{CH}_{4}\right)$; b $17\left(\mathrm{H}_{2} \mathrm{O}\right.$, $\left.\mathrm{NH}_{3}\right)$; c $18\left(\mathrm{H}_{2} \mathrm{O}\right)$; d 27( $\left.\mathrm{HCN}\right)$, e $41\left(\mathrm{CH}_{3} \mathrm{CN}\right)$, f $44\left(\mathrm{CO}_{2}\right)$, g $46\left(\mathrm{NO}_{2}, \mathrm{CO}_{2}\right)$, h 51(alkyl radicals), i 64 (SO2) as well as $\mathbf{j}$ benzene $(\mathrm{m} / \mathrm{z}, 78)$ thermal decomposition of AC unmodified (black line) and modified with OVA and LSZ at 3, 5 and 11 for the initial concentration of the biopolymer equal to $500 \mathrm{ppm}$
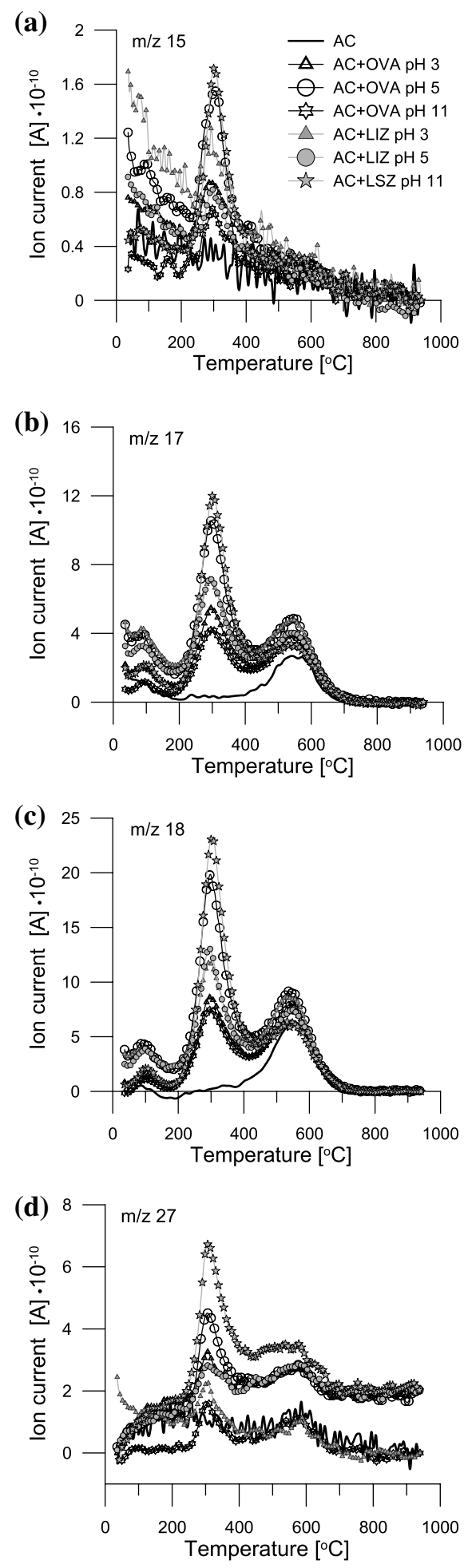
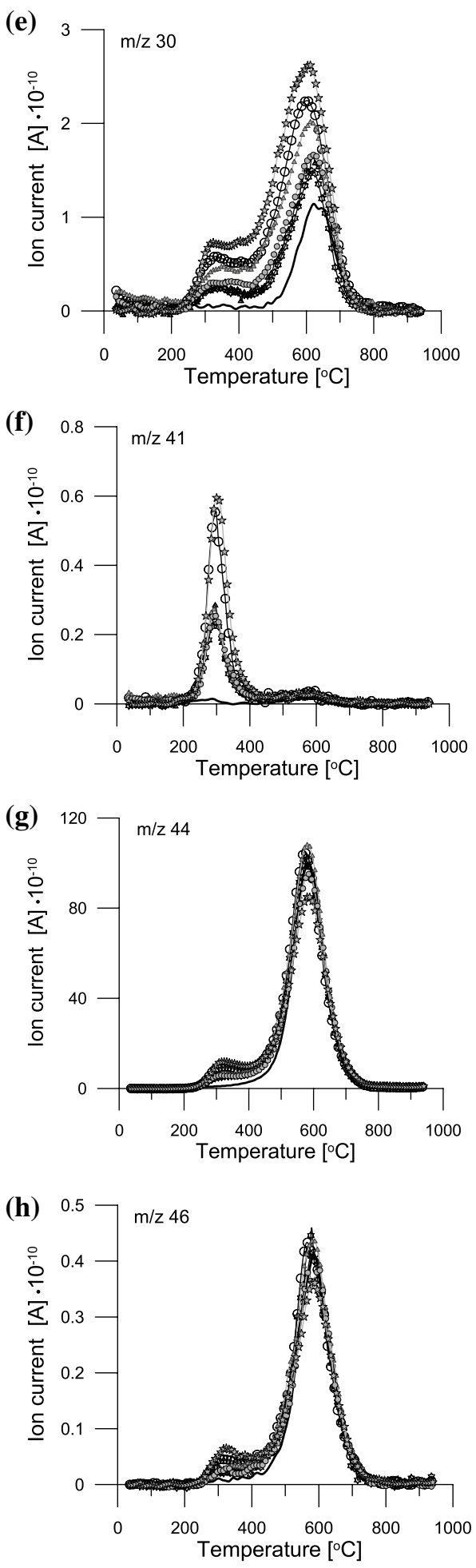
Fig. 8 (continued)
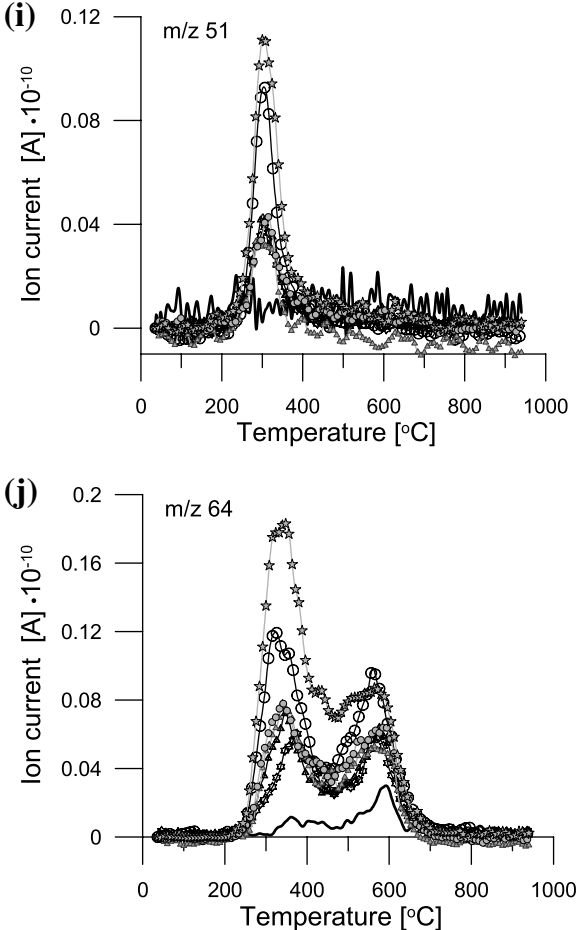

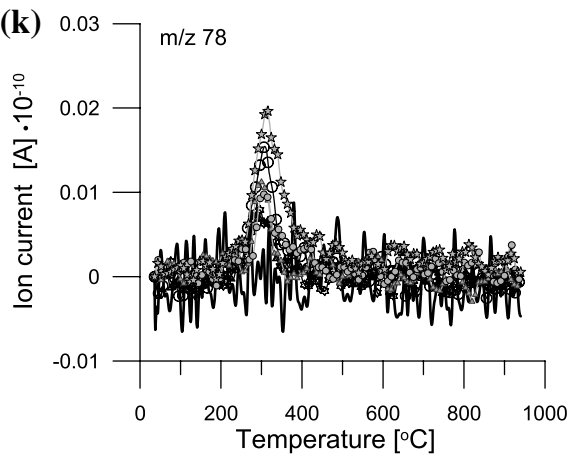

\section{Declarations}

Conflict of interest On behalf of all authors, I state that there is no conflict of interest.

Open Access This article is licensed under a Creative Commons Attribution 4.0 International License, which permits use, sharing, adaptation, distribution and reproduction in any medium or format, as long as you give appropriate credit to the original author(s) and the source, provide a link to the Creative Commons licence, and indicate if changes were made. The images or other third party material in this article are included in the article's Creative Commons licence, unless indicated otherwise in a credit line to the material. If material is not included in the article's Creative Commons licence and your intended use is not permitted by statutory regulation or exceeds the permitted use, you will need to obtain permission directly from the copyright holder. To view a copy of this licence, visit http://creativecommons.org/licenses/by/4.0/.

\section{References}

Armstrong JK, Wenby RB, Meiselman HJ, Fisher TC (2004) The hydrodynamic radii of macromolecules and their effect on red blood cell aggregation. Biophys J 87:4259-4270

Boehm HP (1994) Some aspects of the surface chemistry of carbon blacks and other carbons. Carbon 32:759-769

Buijs J, Hlady V (1997) Adsorption kinetics, conformation and mobility of the growth hormone and lysozyme on solid surfaces, studied with TIRF. J Colloid Interface Sci 190:171-181

Chrzanowska A, Deryło-Marczewska A (2019) Mesoporous silica/ protein biocomposites: surface, topography, thermal properties. Int J Biol Macromol 139:531-542

Deryło-Marczewska A, Mirosław K, Marczewski AW, Sternik D (2010) Studies of adsorption equilibria and kinetics of o-, m-, p-nitro- and chlorophenols on microporous carbons from aqueous solutions. Adsorption 16:359-375

Dunn MS, Brophy TW (1932) Decomposition points of the amino acids. J Biol Chem 99:221-229

Figueiredo JL, Pereira MFR, Freitas MMA, Orfao JM (1999) Modification of the surface chemistry of activated carbons. Carbon 37:1379-1389

Hartvig RA, Van de Weert M, Ostergaard J, Jorgensen L, Jensen H (2011) Protein adsorption at charged surfaces: the role of electrostatic interactions and interfacial charge regulation. Langmuir 27:2634-2643

Hlady V, Buijs J, Jennissen HP (1999) Methods for studying protein adsorption. Methods Enzymol 309:402-429

Howland, R., Benatar, L (2002) STM/AFM mikroskopy ze skanującą sonda - elementy teorii i praktyki. Park Scientific Instruments, tłum: M. Woźniak i J.A. Kozubowski, Warszawa.

Jennisen HP (1981) Multivalent interaction chromatography as exemplified by the adsorption and the desorption of skeletal muscle enzymes on hydrophobic alkyl-agaroses. J Chromatogr 215:73-85

Jennisen HP, Botzet G (1979) Protein binding to two-dimensional hydrophobic binding-site lattices: adsorption hysteresis on immobilized butyl residues. Int J Biol Macromol 1:171-179

Jennisen HP, Demirolgou A (1992) Base atom recognition in protein adsorption to alkyl agaroses. J Chromatogr 597:93-100

Jennisen HP, Heilmeyer LMG (1975) General aspects of hydrophobic chromatography. Adsorption and elution characteristics of some skeletal muscle enzymes. Biochemistry 147:754-760

Kadir A, Lakowicz JR, Geddes CD (2005) Plasmon light scattering in biology and medicine: new sensing approaches, visions and perspectives. Curr Opin Chem Biol 9:538-544

Kato TK, Fujimaki M (1971) Thermal degradation of aromatic amino acids. Agric Biol Chem 35:2106-2112

Kęcki Z (2013) Podstawy spektroskopii molekularne. Wydawnictwo Naukowe PWN, Warszawa 
Kuzema PO, Laguta IV, Stavinskaya ON (2016) TGA and TPD MS study of silica-gelatin materials. Chem Phys Surf Technol 7:145-156

Maiti NC, Apetri MM, Zagorski MG, Carey PR, Anderson VE (2004) Raman spectroscopy characterization of secondary structure of natively unfolded proteins: $\alpha$-synuclein. J Am Chem Soc 126:2399-2408

Nakamura K, Kiriyama M, Takada A, Maeda H, Nemoto N (1997) Structure and dynamics of ovalbumin gels III Solvetr effects. Rheol Acta 36:252-261

Neumann PM, Weissman R, Stefano G, Mancuso S (2010) Accumulation of xylem transported protein at pit membranes and associated reductions in hydraulic conductance. $\mathrm{J}$ Exp Bot 61:1711-1717

Parmar AS, Muschol M (2009) Hydratation and hydrodynamic interactions of lysozyme: effects of chaotropic versus cosmotropic ions. Biophys J 97:590-598

Paulik F (1995) Special trends in thermal analysis. John Wiley and Sons, New York

Pezennec S, Gauthier F, Alonso C, Granter F, Crogunnec T, Brule G, Renault A (2000) The protein net electric charge determines the surface rheological properties of ovalbumin adsorbed at the air-water interface. Food Hydrocoll 14:463-472

Rabe M, Verdes D, Seeger S (2011) Understanding protein adsorption phenomena at solid surfaces. Adv Coll Interface Sci 162:87-106

Rezwan K, Studart AR, Voros J, Gauckler LJ (2005) Change of $\zeta$ potential of biocompatibile colloidal oxide particles upon adsorption of bovine serum albumin and lysozyme. J Phys Chem B 109:14469-14474

Schaaf P, Dejardin P, Schmitt A (1987) Reflectometry as a technique to study the adsorption of human fibrinogen at the silica/solution interface. Langmuir 3:1131-1135

Skowroński JM (1979) Thermal investigation of active carbons in presence of air. J Thermal Anal Calorim 16:463-469

Smith WE, Dent G (2005) Modern Raman spectroscopy-a practical approach. Willey, New Jersey

Sternik D, Wiśniewska M, Nowicki P (2019) Thermal degradation of peat-based activated carbons covered with mixed adsorption layers of PAA polymer and SDS surfactant. Thermochim Acta 676:71-83

Szewczuk-Karpisz K, Wiśniewska M (2014) Adsorption properties of the albumin-chromium(III) oxide system-effect of solution $\mathrm{pH}$ and ionic strength. Soft Mater 12:268-276
Szewczuk-Karpisz K, Wiśniewska M, Nowicki P, Oleszczuk P (2020) Influence of protein internal stability on its removal mechanism from aqueous solutions using eco-friendly horsetail herb-based engineered biochar. Chem Eng J 388:124156

Szymański GS, Karpiński Z, Biniak S, Świątkowski A (2002) The effect of the gradual thermal decomposition of surface oxygen species on the chemical and catalytic properties of oxidized activated carbon. Carbon 40:2627-2639

Thompson HG (1993) A user's guide to ellipsometry. Academic Press, San Diego

Tollefen DM, Feagler JR, Majerus PWJ (1971) The binding of thrombin to the surface of human platelets. J Biol Chem 246:2646-2651

Weiss IM, Muth C, Drumm R, Kirchner HOK (2018) Thermal decomposition of the amino acids glycine, cysteine, aspartic acid, asparagine, glutamic acid, glutamine, arginine and histidine. BMC Biophys 11:2

Wiśniewska M, Nowicki P, Nosal-Wiercińska A, Pietrzak R, Szewczuk-Karpisz K, Ostolska I, Sternik D (2017) Adsorption of poly(acrylic acid) on the surface of microporousactivated carbon obtained from cherry stones. Colloids Surf A 514:137-145

Wiśniewska M, Wawrzkiewicz M, Polska-Adach E, Fijałkowska G, Goncharuk O (2018) Nanosized silica-titanium oxide as a potential adsorbent for C.I. Acid Yellow 219 dye removal from textile baths and wastewaters. Appl Nanosci 8:867-876

Wiśniewska M, Urban T, Chibowski S, Fijałkowska G, Medykowska M, Nosal-Wiercińska A, Franus W, Panek R, Szewczuk-Karpisz K (2020a) Investigation of adsorption mechanism of phosphate(V) ions on the nanostructured $\mathrm{Na}-\mathrm{A}$ zeolite surface modified with ionic polyacrylamide with regard to their removal from aqueous solution. Appl Nanosci 10:4475-4485

Wiśniewska M, Fijałkowska G, Szewczuk-Karpisz K, Sternik D (2020b) Aggregation and thermal properties of nanostructured montmorillonite covered with mixed adsorption layers of cationic polyacrylamide and hazardous lead(II) ions. Appl Nanosc 10:5499-5510

Yablokov VA, Smel'tsova IL, Faerman VI (2013) Thermal stability of amino acids. Russ J General Chem 83:423-427

Publisher's Note Springer Nature remains neutral with regard to jurisdictional claims in published maps and institutional affiliations. 